\title{
Psycholinguistic Features of Students' Acquisition of Visual-Semantic Image of a Hieroglyph in Studying Japanese*
}

\section{Психолінгвістичні особливості засвоєння студентами візуально-семантичного образу ієрогліфу при вивченні японської мови**}

Lubov Dolynska ${ }^{1}$

Ph.D. in Psychology, Professor

\author{
Любов Долинська ${ }^{1}$ \\ кандидат психологічних наук, \\ професор
}

E-mail: psychologycaf@gmail.com https://orcid.org/0000-0002-1817-1102

Yuliya Naumova ${ }^{2}$

Ph.D. in Psychology, Lecturer
Юлія Наумова 2

кандидат психологічних наук, викладач

E-mail: ulanau@gmail.com

https://orcid.org/0000-0001-5962-115X

Nataliia Shevchenko ${ }^{3}$

Dr. in Psychology,

Professor
Наталія Шевченко ${ }^{3}$ доктор психологічних наук, професор

\author{
E-mail: ShevchenkoNF.20@gmail.com \\ https://orcid.org/0000-0002-5297-6588 \\ ResearcherID: I-2214-2018 \\ ScopusID: 57210214638
}

\footnotetext{
* This study has been done within the framework of the State project and finance support of the Ministry of Education and Science of Ukraine (Registration number 1119U002585).

** Дослідження виконане в рамках Держбюджетного проекту за фінансової підтримки Міністерства освіти і науки України (реєстраційний номер 1119U002585).
} 
${ }^{1}$ National Pedagogical

Dragomanov University

14/8, Turhenivs'ka Str., Kyiv, Ukraine, 01135

${ }^{2}$ Kyiv National Linguistics University
$\square 5 / 7$, Laboratorna Str., Kyiv,
Ukraine, 01150

${ }^{3}$ Zaporizhzhia National University

66, Zhukovskyi Str., Zaporizhzhia, Ukrain, 69600

\author{
${ }^{1}$ Наиіональний \\ педагогічний університет \\ імені М.П. Драгоманова
}

вул. Тургенівська, 14/8, Київ,

Україна, 01135

${ }^{2}$ Київський Наиіональний

лінгвістичний університет

$\triangle$ вул. Лабораторна, 5/7, Київ,

Україна, 01150

\author{
33апорізький національний \\ університет \\ вул. Жуковського, 66, \\ Запоріжжя, Україна, 69600
}

Original manuscript received November 19, 2019

Revised manuscript accepted March 16, 2020

\begin{abstract}
Introduction. The article highlights psycholinguistic features of students' acquisition of visual-semantic image of a hieroglyph in studying Japanese. The choice of the image category is justified by its ability to reflect in individual's consciousness a complete picture of the object of cognition, which corresponds with the specific character of the hieroglyphic script. The visual-semantic image of a hieroglyphic sign has been defined as a complicated cognitive complex (mental image), which is an integral product of visual sensory-perceptual reception of all graphic elements of the hieroglyph formal structure, a coherent vision of it and conceptual representation, embodied in the meaning.
\end{abstract}

Goal. The purpose of the article is to present results of the study of psycholinguistic features of students' acquisition of visual-semantic images of hieroglyphs. The following techniques have been chosen as the main psychodiagnostic tools: "Pictograms" by O. Luria, "Hidden Figures» by K. Gottschaldt, "Matching Familiar Figures» by J. Kagan, "Free Sorting of Objects» by R. Gardner in modification by V. Kolg.

Results. Results of theoretical explorations on the psychological features of the problem of a personality's acquisition of foreign languages, particularly, hieroglyphic, have been presented. It has been shown that interpretive capabilities of hieroglyphic signs are fundamentally different from the usual European method of linguistic codification of reality and that optimization ways of Oriental languages acquisition should be based on the differences between phonemic and hieroglyphic writing. Psycholinguistic peculiarities of students' acquisition of the visual-semantic image of a hieroglyph have been revealed - character and structure of students' visual and meaning images of hieroglyphic meanings have a significantly expressed individuality. The study of individual cognitive learning styles the educational information by students has 
shown that main cognitive skills and abilities are one of the factors of this success in combination with others; quality of the hieroglyphics acquisition improves with a good ability in systematization, generalization, unification of the unit into broad classes, as well as in the tendency to reasonableness.

Key words: hieroglyph, hieroglyphic script, visual-semantic image of a hieroglyph, cognitive learning style of educational information.

\section{Вступ}

Сучасні соціально-економічні тенденції визначають зростання інтересу майбутніх студентів до оволодіння іноземною мовою 3 ієрогліфічною писемністю. Ця зацікавленість зумовлена підвищенням ділових та культурних зв’язків України 3 країнами Сходу. Водночас, все більш актуальним мотивом для молодих людей у виборі ієрогліфічної мови (китайської, японської) стає гуманітарний аспект, який полягає саме у якісному оволодінні мовою, літературою, культурою, які суттєво відрізняється від власної. Цей вектор інтересу має різні витоки: це i захоплення японськими аніме - специфічними анімаційними рисованими фільмами; i інтерес до східної філософії та культури; i краса ієрогліфічної каліграфії; i уподобання ха́йку - традиційного жанру японської поезії тощо. Водночас, як показує практика, мотивація очарування східними мовами різко знижується у студентів вже на першому курсі, коли починається засвоєння ієрогліфіки.

Питанням підвищення ефективності вивчення студентами ієрогліфічних мов як іноземних приділяється увага в науці. Так, О. Асадчих (2007) пропонує впровадження спеціалізованих навчальних вправ для засвоєння усного академічного японського мовлення; С. Байрамова (2016) цю проблему розглядає через формування у студентів слуховимовних навичок на основі когнітивного образу китайської морфеми; Ю. Молоткова (2014) зосереджує увагу на необхідності поетапного засвоєння студентами китайських ієрогліфів при опорі на гніздову організацію ієрогліфічного матеріалу; У. Стрижак (2005) обгрунтовує необхідність врахування різних видів пам'яті тощо. Широке коло питань з ієрогліфіки представлено в працях українського науковця В. Резаненка (1996). 
Проблематика ефективного засвоєння ієрогліфів належить до сфери наукових інтересів японських та китайських дослідників. Так, Йоко Окіта демонструє роботу когнітивних механізмів у тих, хто вивчає ієрогліфіку при прописуванні ними нових ієрогліфів у повітрі (техніка空書 kūsho) (Okita, 2013), доводять ефективність цієї методики Ацуя Йошіда та Нацує Сугая (Yoshida \& Sugaya, 2017); розглядають ефективні стратегії навчання для запам'ятовування ієрогліфів Ецуко Тойода та Цзін Лю (Toyoda, 2001; Jing, 2010), Йошіко Кобаяші (Kobayashi, 2009) зосереджує увагу на ролі метапізнання у вивченні ієрогліфіки.

Кожний такий внесок у досліджувану тему збагачує методологію засвоєння ієрогліфічної мови й відкриває можливості для наукових розробок психолінгвістичних аспектів засвоєння ієрогліфіки, а також створення прикладних моделей оптимізації цього процесу.

Досвід нашої роботи показує, що в закладах вищої освіти, в яких вивчаються східні мови, ієрогліфіка залишається для студентів найскладнішим предметом, а рівень успішності навчальних досягнень переважно низьким. Серед чинників втрати інтересу та низької ефективності опанування східними мовами, окрім інших, нами визначено: психолінгвістичні складнощі інтерпретаційних властивостей ієрогліфічних знаків, відсутність у студентів з базовою фонематичною мовою особливої набутої здатності розпізнавати візуальний образ ієрогліфічних знаків, ігнорування у методиці навчання індивідуальних когнітивних стилів та стратегій засвоєння нового знання студентами.

3 огляду на затребуваність високоефективної підготовки фахівців зі знання ієрогліфічних мов та обмеженість системних розробок психолінгвістичних програм з оптимізації цього процесу, ми вважаємо, що перспективним напрямком засвоєння студентами іноземної мови з ієрогліфічною писемністю, зокрема японської, $\epsilon$ опора на образну сферу студентів, а саме - візуально-семантичні образи графічних елементів цієї писемності.

Об'єкт дослідження - засвоєння студентами образу ієрогліфа.

Предмет дослідження - психолінгвістичні особливості засвоєння студентами візуально-семантичного образу ієрогліфа при вивченні японської мови. 
Метою статті $є$ презентація результатів дослідження психолінгвістичних особливостей засвоєння студентами візуальносемантичних образів ієрогліфів.

Для вивчення психолінгвістичних аспектів засвоєння студентами візуально-семантичних образів ієрогліфів було сформульовано наступні завдання:

1) вивчити особливості формування студентами образів, зокрема, візуальних образів уявлень та образів значення, що формуються у свідомості студентів при сприйнятті ними ієрогліфічних знаків різного рівня складності;

2) дослідити індивідуальні когнітивні стилі засвоєння студентами навчальної інформації;

3) зіставити особливості формування образів та індивідуальні когнітивні стилі студентів.

Приступаючи до дослідження ми виходили 3 того, що ієрогліф як графічний елемент мови, що передає значення, представлений у нашій психіці складним візуально-семантичним образом, а опанування іноземною мовою в системі «фонематична фонематична» та в системі «фонематична - ієрогліфічна» має психолінгвістичні відмінності.

Вибір категорії образу обгрунтовано нами його здатністю відображувати у свідомості індивіда цілісну картину предмета пізнання, що відповідає специфіці ієрогліфічного письма. Ігнорування цієї психологічної специфіки у вивченні східних мов зводить процес засвоєння їх графічних знаків до механістичності, що зумовлює недостатнє рівень опанування ієрогліфікою, а відтак і зниженням мотивації вивчення ієрогліфіки.

\section{Методи та методики дослідження}

У процесі дослідження психолінгвістичних особливостей засвоєння студентами візуально-семантичних образів ієрогліфів використано комплекс теоретичних та емпіричних методів. У якості психодіагностичного інструментарію, який забезпечував надійність та валідність досліджуваних параметрів, представлених у статті, використано: методику «Піктограми» О. Лурія (Методика «Пиктограмма» (н. д.)) - для дослідження особливостей формування 
візуальних образів, пов'язаних з поняттями; методику «Приховані фігури» К. Готтшальдта (Методика «Фигуры Готтшальдта» (н. д.)) (полезалежний/поленезалежний когнітивний стиль) - для розпізнавання ієрогліфічних елементів у складі таких, що $є$ більш складними; методику «Порівняння схожих малюнків» Дж. Кагана (Методика «Сравнение похожих рисунков» (н. д.)) (рефлексивний/ імпульсивний когнітивний стиль) - для характеристики індивідуальних відмінностей у схильності приймати рішення швидко або повільно; методику «Вільне сортування об’єктів» Р. Гарднера у модифікації В. Колга (Методика «Свободная сортировка объектов» (н. д.)) (широкий/вузький діапазон еквівалетності) - для виявлення ролі категоризації у роботі з ієрогліфічним матеріалом.

Для обробки матеріалів досліджень використовувалися методи математичної статистики.

Дослідження особливостей засвоєння студентами візуальносемантичних образів ієрогліфів проводилось на базі факультетів східних мов, Київського національного лінгвістичного університету КНУ та НПУ імені М.П. Драгоманова. Вибірку респондентів склали студенти віком від 18 до 23 років, серед яких 86 студентів II-IV курсів рівня вищої освіти «бакалаврський» (74 - дівчат, 12 юнаків) та 34 студентів I курсу рівня вищої освіти «магістерський» (27 - дівчат, 7 - юнаків). Загальна кількість респондентів - 120 осіб.

\section{Результати та дискусії}

Вибору методів дослідження передувало проведення аналізу наукових джерел, який дозволив констатувати, що проблема засвоєння іноземних мов розробляється сучасною прикладною лінгвістикою, психолінгвістикою, педагогікою, педагогічною психологією тощо.

За даними теоретичного аналізу окресленої проблеми, засвоєння є категорією навчальної діяльності, яка має складну внутрішню структуру, що охоплює пізнавальну, мотиваційну, афективну сфери особистості. Це складний процес присвоєння індивідом сукупності знань, способів дій (умінь, навичок), соціальнокультурного досвіду поколінь, етичних норм поведінки у суспільстві, який має результуючий ефект (якість, міцність, системність) i 
дозволяє адекватно вирішувати певні навчальні, життєві, професійні завдання (Рубинштейн, 1997; Щедровицкий, 2005 та ін.). Головними критеріями засвоєння виступають можливості екстеріоризації знань, втілення їх у зовнішніх, практичних предметних діях та творчих проектах. Результативність засвоєння іноземних мов у закладах вищої освіти зумовлена не усередненими умовами організації навчального процесу, а індивідуалізованими підходами щодо створення оптимальних умов опанування навчальним матеріалом для кожного студента (Сімонок, 2014; Шевченко, 2018).

Процес засвоєння ієрогліфічної писемності за своєю суттю мало чим відрізняється від процесу засвоєння іншого письма. У методичному плані існують ті ж самі загальні вимоги, що й при вивченні західноєвропейських мов: оволодіння графічними та моторними навичками письма, навичками зорового сприймання інформації (читання), знання лексики тощо. Семантика ієрогліфа, як і слова, визначається комбінацією символів. Проте, ця комбінація $\epsilon$ відмінною: графічна презентація ієрогліфа будується за іншими, ніж слова фонематичної мови, правилами. Фонематичне письмо смисл мовних висловлювань переводить у свідомість індивіда через озвучування (навіть якщо текст прочитується не вголос, це відбувається у внутрішньому мовленні), тоді як перцепція ієрогліфу, перш за все, візуальна. Його ідентифікація потребує здатності розпізнавати графічні композиційні елементи в їх образно-смисловій єдності через візуальне сприйняття.

Ієрогліфічна писемність - це писемність, де графічний знак у вигляді умовного зображення служить символом, знаком, що самостійно передає семантику поняття. Закладена в ієрогліфічному знаку дешифровка смислу поняття в образному полі створювалась історичною. Суттєвою семіотичною особливістю давньокитайських текстів, які стали витоками сучасної ієрогліфічної писемності Китаю та Японії, є те, що знаки цієї писемності з самого початку свого виникнення були малюнками, що являли своєрідний вид фіксації того, що побачив їх творець (Мартыненко, 2007). Вказівка на зміст рисунка фіксувалась його безпосереднім зображенням, що передавало зміст свідомості без слів. Водночас, ієрогліф не є «чистою» ідеограмою, і його значення не може бути зрозумілим поза системою писемності, до якої він належить. Ці графічні знаки несуть у собі семантику i, як правило, виражають поняття, 
a не конкретні лексичні (словникові) значення (Кочергин, 2006). Це не просто слово, а лінгвокультурема, яка допомагає розкривати специфічну лінгвокультурологічну картину світу i зрозуміти менталітет носіїв цієї мови, оскільки в ієрогліфі закладена історія і культура народу (Кай, 2012).

Для китайських та японських шкіл давньою традицією $\epsilon$ заучування ієрогліфів шляхом багаторазового їх прописування, для чого розробляються спеціальні прописи і підручники з ієрогліфіки. Ця технологія себе виправдовує у країнах 3 використанням ієрогліфічної писемності, оскільки діти, мозок яких вже деякою мірою звик до сприйняття такого типу знаків через ієрогліфічну опосередкованість у повсякденному житті, під час навчання ієрогліфіки у школі співвідносить графічне накреслення ієрогліфа (нове знання та актуалізоване пасивне старе знання) з його значенням та читанням (старе знання). У студентів (дорослих суб'єктів навчання), що опановують ієрогліфіку як писемність іноземної мови, яку вони вивчають, і для яких рідною є фонематична мова, при вивченні східних мов з відмінною кодифікацією графічних знаків, виникає необхідність урахування й інших, зокрема психологічних механізмів цього процесу. Розуміння ієрогліфічних знаків потребує більшої кількості мисленнєвих операцій, ніж літер, що пов'язано зі складністю графіки, багатоплановістю взаємодії композиційних елементів iї формально-семантичної структури.

Згідно 3 результатами аналізу теоретичних розробок, категорія образу у психології має широкий спектр трактування як в історичному ракурсі його вивчення, так i в рамках теорії відображення, крізь призму якої психічний образ переважно розглядається у вітчизняній науці. Узагальнено можна стверджувати, що психічний образ являє собою будь-яке відображення предметів та явищ об'єктивної дійсності у свідомості людини, є суб'єктивним і вторинним по відношенню до дійсності. Оскільки він за своєю природою пов'язаний зі свідомістю людини, його структуру можна розглядати за Ф. Василюком (Василюк, 1993), де образ свідомості постає як структура 3 п'яти вимірювань: значення, предмета особистісного смислу, знаку (слова) і чуттєвої тканини, що наділяє образ специфічними індивідуальними ознаками.

Візуально-семантичний образ ієрогліфу ми визначаємо як складний когнітивний комплекс (розумовий образ), що $\epsilon$ 
інтегральним продуктом візуального сенсорно-перцептивного сприйняття (чуттєвий образ) усіх графічних елементів формальної структури ієрогліфу, цілісного уявлення про нього (закріпленого в образній пам'яті) та понятійного (смислового) відображення, закріпленого значенням. Він $\epsilon$ результатом складної обробки свідомістю студентів інформації, що отримується ними у процесі освоєння ієрогліфічної писемності (Наумова, 2019).

Важливим психолінгвістичним аспектом при засвоєнні ієрогліфіки $є$ специфіка формування студентами візуальносемантичного образу ієрогліфу. Для іï виявлення був застосований модифікований варіант методики «Піктограми» О. Лурія (Методика «Пиктограмма» (н. д.)). Студентам пропонувалось запам'ятати 10 нових (таких, що не вивчалися раніше) ієрогліфічних знаків разом 3 їх понятійним значенням (перекладом) шляхом створення візуальних образів самих ієрогліфів та образів їх значень, пропонувалось уявити образи і записати ці візуалізації коротко вербально. За годину студентів просили відтворити ієрогліфи та їх значення такими, як їм вдалося їх запам'ятати, з опорою на сформовані раніше образи.

Було з'ясовано, що образи ієрогліфів, якими оперують студенти в якості опори при їх запам'ятовуванні, являють собою розумовий образ, що відображає частку індивідуальної реальності того, хто його створює, представлений суспільним культурним досвідом, присвоєним індивідом, а також його власним досвідом взаємодії 3 довкіллям та способами репрезентації. При формуванні візуальних образів ієрогліфів українські студенти оперують переважно образами світу своєї культури. Наприклад, дуже поширеними $є$ образи, де фігурують суто національні українські архетипи («біла земля (土), яку сиплють на тарілочку (皿) та відправляють до рота (口)» (ієрогліф 塩 «сіль»); «могилка, на ній посадили дерево (木)», (ієрогліф 植 «саджати рослини»), «дідусь у брилі 3 палицею на одній нозі» (ієрогліф 停 «зупинити») тощо і значно менше образів східної архетипіки («китайський мудрець з борідкою посміхається»; «під дахом серце (心) думає» (ієрогліф 念 «ідея»); «самурай у броні» (ієрогліф 賞《нагорода, премія»).

В образах ієрогліфів переважають усі компоненти структурної моделі Ф. Василюка (1993). Наприклад,

- предметний зміст: «очі, що дивляться вниз на перевернутий стіл, ніжки якого схожі на металеві труби» (ієрогліф 管 «труба»); 
Psycholinguistic Features of Students'Acquisition...

«людина тримає нагороду над головою» (ієрогліф 賞 «нагорода, премія»);

- особистісний смисл: «дівчата винесли 3 палаючого дому дітей» (ієрогліф 救 «рятувати»); «мир, дах, дім 家, багатство» (ієрогліф 稼 «заробляти»).

- зміст самого поняття, його значення: «зовсім інші пропорції у кожній 3 ліній» (ієрогліф 差 «різниця»); «рис (禾) у домі (家) те, що заробили» (ієрогліф 稼 «заробляти»).

- знак: «вівця 羊 3 хвостом, катаканське «е»» (ієрогліф 差 «різниця»), «золота рибка 魚 зустріла вівцю (羊)» (ієрогліф 鮮 «яскравий»);

- чуттєва тканина (відчування): «такий, що видимий наскрізь, незатьмарений» (ієрогліф 気 «дух», «настрій») «душити шовковим шарфом» (ієрогліф 妬 «ревнувати»); «сніжинка, що тане, кришталево чисте море» (ієрогліф 透 «прозорий»), «почуття смутку і душевного болю» (ієрогліф 苦 «страждати»).

- Зафіксовано чимало образів, де має місце комбіноване домінування декількох полюсів: «знання, подаровані сонцем (日)» (ієрогліф 智 «інтелект, розум»), «коли багато щастя (幸) та кіл 丸 (монет), можна виконати що завгодно» (ієрогліф 執 《виконувати») значення і знак; «їсти (食), рука, війна» (ієрогліф 餓 «голод»), «через 9 років щось здійсниться і буде щастя (幸)» (ієрогліф 執 «виконувати») - знак, особистісний смисл тощо.

Якісна обробка отриманого у дослідженні матеріалу виявила у респондентів майже повну відсутність одноманітності i повторень у візуальних образах ієрогліфів. Були визначені також такі типові ознаки створених студентами образів - реалістичністьметафоричність, статичність-динамічність, цілісність-структурність, а саме: первинний статистичний аналіз показав, що реалістичністьметафоричність створених студентами образів виявилася у 45 досліджуваних, що складало 37,5\% вибірки; статичністьдинамічність у 34 респондентів або 28,3\% вибірки та цілісністьструктурність - у 41 студента, тобто у 34,2\% вибірки.

Показник «реалістичність-метафоричність» характеризує спосіб мислення та віддзеркалює досвід особистості: реалістичність демонструє предметність, шаблонність, стереотипність мисленнєвих процесів («людина (人), зіткнення зі стіною, кришка, дім, дах» (ієрогліф 停 «зупинити»)), метафоричність - прагнення запобігати 
банальностей, наявність креативності, певною свободи думки («стрілу в рот запустити - день не продовжити» (ієрогліф 智 «інтелект, розум»)). «Статичність - динамічність» - це композиційні характеристики образів. Статичні образи - чіткі, конкретні, 3 відсутністю простору i руху («нитка (系), кришка, тарган 3 вусиками» (ієрогліф 締 «зав’язувати, затягувати»)); динамічні, навпаки - необмежені просторово, містять ідею руху («рисове колосся хитається біля прозорої води (ієрогліф 透 «прозорий»), «двоє людей біжать, узявшись за руки» (ієрогліф 堤《дамба»)). «Цілісністьструктурність» - характеристики сприйняття, які дозволяють виділяти окремі елементи, ознаки, властивості сприйнятого стимулу і об’єднувати потім їх у цілісну структуру образу. Ця характеристика в образі виявляє себе у деталізації («спис та лук» (ієрогліф 狩 «полювання»), «людина, стовп, будка» (ієрогліф 塀 «огорожа»)) чи в узагальненості сприйняття («виправляти екологію - це саджати дерева (木)» (ієрогліф 植 «саджати рослини»)), фіксації на окремих деталях чи охопленні сутності.

Семантичні образи ієрогліфів будуються за принципом асоціативної схожості предметів, властивостей, ознак, ситуацій до стимульного поняття, виявленого власним досвідом суб'єкта; за принципом логічності, визначеності поняття; за принципом виявлення емоційного ставлення до змісту чи наслідків або морально-етичної оцінки закріплених у понятті явищ дійсності; іносказання (метафоричності).

Аналіз зібраних під час проведення дослідження образних продуктів (а це більше ніж 2400 одиниць) засвідчив, що кожний студент має свій особливий стиль і орієнтується на домінантність однієї-двох структурних типологій. Створені студентами образи мають істотно виражену індивідуальність, що підтверджує наше переконання про хибність застосування готових асоціацій для запам'ятовування ієрогліфічних знаків.

$\mathrm{He}$ менш вагомим психолінгвістичним аспектом при засвоєнні ієрогліфіки $є$ роль індивідуальних когнітивних стилів, що обумовлюють ефективність навчання (Бондар, 2003; Холодная, 2002).

Емпіричне дослідження здійснювалось 3 використанням стандартизованих методик оцінки когнітивних стилів, а саме: полезалежність/поленезалежність (за методикою «Приховані фігури» 
К. Готтшальдта), вузькість/широта діапазону еквівалентності (за методикою «Вільне сортування об’єктів» Р. Гарднера у модифікації В. Колга), імпульсивність/рефлексивність (за методикою «Порівняння схожих малюнків» Дж. Кагана).

Опрацювання отриманих даних виявило перевагу у респондентів поленезалежного когнітивного стилю - 59,4\%. Відповідно у респондентів полезалежного когнітивного стилю 40,6\% від усієї вибірки. Такі результати трактуються нами як цілком логічні, оскільки стиль полезалежності/поленезалежності відображає особливості вирішення, насамперед, перцептивних завдань, до яких відноситься й засвоєння ієрогліфічної писемності. Поленезалежна особа менше схильна до впливу контексту, а тому легше вирішує перцептивні завдання (наприклад, виокремлення фігури з фону).

Найбільш чіткі відмінності між полезалежними i поленезалежними респондентами проявляються в особливостях сприйняття. Полезалежні респонденти більшою мірою схильні до різного роду ілюзій сприйняття. На відміну від полезалежних, поленезалежні респонденти сприймають «картинку» більш структурованою. Це проявляється у тому, що для перших якості виділеного фокусом об'єкта сприймаються самостійно, окремо від інших об'єктів, що одночасно з цим об'єктом діють на аналізатори. Інакше кажучи, сприйняття поленезалежних $є$ більш аналітичним, сприйняття полезалежних - синтетичним.

Порівняння візуальних образів, створених студентами 3 поленезалежним та полезалежним когнітивними стилями показало, що для перших (поленезалежних) в образах характерними $\epsilon$ домінування полюсу предмета, причому, переважно у статичному варіанті. Предметний світ у таких образах переважно чіткий, логічний, добре упізнаваний у графічних елементах ієрогліфів (лук, стріли, дах, будинок, квітка, дерево, хрест, хвіст, меблі, драбина тощо), рідше - відтворений особистісним смислом, власною для індивіда історією або вигаданою, проте, досить реалістичною (мусульманин, кріпак, ларьок, баскетбольне кільце, Гадзила, китайська чайна, обладунки воїна тощо).

Для виявлення ролі категоризації у роботі з ієрогліфічним матеріалом застосовувалась методика Р. Гарднера «Вільне сортування об'єктів» у модифікації В. Колга (Методика «Свободная сортировка объектов» (н. д.)). У якості стимульного матеріалу 
для сортування були використані написані на окремих картках 35 слів, які характеризують різні аспекти категорії «час»: декада, мить, ера, сьогодні, квартал, тиждень, момент, завтра, хвилина, скоро, семестр, опівдні, місяць, століття, епоха, вчора, вічність, тисячоліття, рік, година, мить, зміна, опівночі, сутінки, вік, зараз, секунда, вечір, чверть, день, світанок, ніч, доба, ранок, мілісекунди. Тобто студенти оперували поняттями. Досліджуваним пропонувалося розкласти картки на групи найбільш зручним, логічним і природним, з їх точки зору, способом. Підкреслювалося, що завдання не має єдино правильного рішення і що кожен може розкладати групи по-своєму».

Статистичний аналіз отриманих результатів за вказаною методикою показав, що близько 3/4 досліджуваних студентів (72,0\%) згрупували поняття практично однаково у 3-4 групи, за винятком невеликої кількості (до 10 карток в одну групу). Цей факт не дозволяє зробити висновок про повну ідентичність понять. Досліджуване явище свідчить про можливі відхилення від переважної кількості респондентів.

Вузький/широкий діапазон еквівалентності характеризує індивідуальні відмінності в особливостях орієнтації на риси подібності або риси відмінності об'єктів. Вузький діапазон еквівалентності передбачає більш деталізовану категоризацію вражень, що дозволяє говорити про використання цими людьми більш точних стандартів в оцінці відмінностей об’єктів.

Аналіз створених студентами візуальних (таких, що базуються виключно на зоровому сприйнятті ієрогліфа, безвідносно до його лексичної семантики) та семантичних (таких, що створюються на основі сприйняття саме лексичного значення) образів ієрогліфів показав, що респонденти 3 вузьким діапазоном еквівалентності формують образи, насичені деталями i поясненнями («звір, тварина, убита, яку людина несе на спині у сітці», «ліс, у якому чисте повітря, величні сосни качаються на вітру, а по траві повзе равлик»), або обмежуються переліком асоціацій («фемінізм», «ліс, тварини, смерть», «робота, сила»). В їхніх образах переважає доля динаміки і цілісності.

У візуальних та семантичних образах ієрогліфів респондентів 3 широким діапазоном еквівалентності наявна схильність до інтелектуалізації образів, котрі мають більше змістовних 
характеристик, властивостей понять («цінність, важливість, обмеженість у кількості», «кінцівка, 90 градусів, суглоб», «такий, що видимий наскрізь, незатьмарений», «верхня частина колодязя із відром» тощо). Їхні образи переважно статичні, структурні.

На нашу думку, широта діапазону еквівалентності як здібність до орієнтації на риси схожості об’єктів у поєднанні з уміннями швидко виділяти елементи із загального поля і $\epsilon$ тим «секретом», що забезпечує успішність опанування ієрогліфічного письма.

Оцінка імпульсивності/рефлексивності як когнітивної стильової характеристики, що виявляє індивідуальні особливості індивіда в ситуації прийняття рішення, $\epsilon$ однією 3 детермінант успішності засвоєння ієрогліфічних мов. Нас цікавила не кількісна перевага одного полюсу стилю над іншим, а якісні можливості ефективно оперувати обома когнітивними стилями. Для цього була використана методика Дж. Кагана «Порівняння схожих малюнків» (Методика «Сравнение похожих рисунков» (н. д.)), для виконання якої досліджувані повинні були знайти повністю ідентичне зображення фігури-еталону предмета, що розташований зверху тестового аркушу, з восьми майже ідентичних зображень цього ж предмета, розташованих нижче еталонного.

Вважається, що особи 3 імпульсивним стилем швидко висувають гіпотези в ситуації альтернативного вибору, але при цьому допускають багато помилкових рішень. Для осіб 3 рефлексивним стилем характерний уповільнений темп прийняття рішення, що, в силу ретельного попереднього аналізу гіпотез, знижує кількість допущених ними помилок. Тобто сама по собі рефлексивність не забезпечує успішності в освоєнні ієрогліфіки. В той же час імпульсивний стиль явно стає перепоною у досягненні ефективних результатів.

Огляд образів, створених студентами для мнемічних опор 3 тим чи іншим стилем рішення завдань показав, що у рефлексивних студентів образи є більш цілісними, ніж структурними, вербальна презентація образу у них стисла і лаконічна. Очевидно, в цьому виражається властива рефлексивним особам виваженість на етапі осмислення завдання, аналізу вихідних його положень, тому на виході продукт-результат вже не наділяється додатковими поясненнями, він є більш точним. Респонденти 3 імпульсивним стилем навпаки обтяжують, «роздувають» образ, наділяють його 
додатковими характеристиками. Також для них характерною $\epsilon$ метафоричність образів, іронічність. За результатами отриманих даних було виявлено значну перевагу у респондентів рефлексивного стилю $-68,7 \%$ у порівнянні $з$ імпульсивним $-31,1 \%$.

Вивчення індивідуальних когнітивних стилів засвоєння студентами навчальної інформації показало, що окремі когнітивні вміння та здібності виступають детермінантами успішності у комбінації з іншими, зокрема, підвищують ефективність засвоєння ієрогліфічного письма у процесі навчання, уміння структурувати сприйняте, швидко та чітко виділяти елементи із загального поля, реорганізовувати його (поленезалежність). Водночас, результативність засвоєння ієрогліфіки підсилюється при належному володінні уміннями систематизувати, узагальнювати, об'єднувати одиниці у широкі класи (широкий діапазон еквівалентності), а також при схильності до розсудливості, зваженості при прийнятті рішення у вирішенні завдань (рефлексивність).

Статистичне дослідження показників рефлексивності за допомогою кореляційного аналізу дозволило виявити достатньо сильну взаємозалежність цих показників i результативності засвоєння ієрогліфіки (коефіцієнт кореляції Пірсона склав 0,62 при рівні значущості 0,05 . Коефіцієнт розрахований за допомогою вбудованої статистичної функції КОРРЕЛ електронного додатку MSExcel.

Аналіз показників індивідуальних когнітивних стилів засвоєння студентами навчальної інформації (поле залежний поленезалежний, вузький-широкий діапазон еквівалентності, рефлективність - імпульсивність) за допомогою Стьюдента показав неоднорідність групи досліджуваних (табл. 1).

Таблиця 1. Розрахунки t-критерію Стьюдента оцінки однорідності груп досліджуваних на рівні значущості $\alpha=0,05$ за індивідуальними когнітивними стилями (при $\mathrm{t}_{\text {експ }}>\mathrm{t}_{\text {таб̆ }}-$ групи неоднорідні)

\begin{tabular}{lccc}
\hline \multirow{2}{*}{$\begin{array}{l}\text { Статистичні } \\
\text { показники }\end{array}$} & \multicolumn{3}{c}{ Індивідуальні когнітивні стилі } \\
\cline { 2 - 4 } & $\begin{array}{c}\text { полезалежний - } \\
\text { поленезалежний }\end{array}$ & $\begin{array}{c}\text { вузький - широкий } \\
\text { діапазон еквівалентності }\end{array}$ & $\begin{array}{c}\text { рефлективність - } \\
\text { імпульсивність }\end{array}$ \\
\hline Середнє & 0,988 & 0,8798 & 0,9105 \\
Дисперсія & 0,0314 & 0,0048 & 0,0031 \\
\hline
\end{tabular}


Psycholinguistic Features of Students'Acquisition...

Значення t-критерію за даними двох груп досліджуваних

$\mathrm{t}_{\text {експ }}$

табал вузький широкий діапазон еквівалентності рефлективність -

імпульсивність

2,185

2,02 полезалежний поленезалежний

2,639

Кореляційно-регресійний аналіз результатів засвоєння студентами візуально-семантичного образу ієрогліфу при вивченні японської мови не виявив залежності цих результатів від віку і статі досліджуваних.

\section{Висновки}

У статті розкрито психолінгвістичні особливості засвоєння студентами візуально-семантичного образу ієрогліфу при вивченні японської мови. Серед чинників низької ефективності опанування ієрогліфічними мовами визначено психолінгвістичні складнощі інтерпретаційних властивостей ієрогліфічних знаків, відсутність у студентів з базовою фонематичною мовою особливої здатності розпізнавати візуальний образ ієрогліфічних знаків, ігнорування в навчанні індивідуальних когнітивних стилів засвоєння навчальної інформації. Показано, що ідентифікація ієрогліфів студентами 3 базовою фонематичною мовою відбувається на основі сприйняття загальної конфігурації графічних композиційних елементів в їх образно-смисловій єдності.

Виявлено низку психолінгвістичних особливостей засвоєння студентами візуально-семантичного образу ієрогліфу при вивченні японської (або китайської) мови: характер та структура створених студентами як візуальних образів так і образів значень ієрогліфів має суттєво виражену індивідуальність; вивчення індивідуальних когнітивних стилів засвоєння студентами навчальної інформації (поле залежний - поленезалежний, вузький-широкий діапазон еквівалентності, рефлективність - імпульсивність) показало, що окремі когнітивні вміння та здібності самі по собі не зумовлюють успішності у освоєнні ієрогліфічної писемності, а виступають чинниками цієї успішності у комбінації з іншими; результативність засвоєння ієрогліфіки підсилюється при хорошому володінні уміннями систематизувати, узагальнювати, об'єднувати одиниці 
у широкі класи (широкий діапазон еквівалентності), а також при схильності до розсудливості, зваженості при прийнятті рішення у вирішенні завдань (рефлексивність).

Проведене дослідження відкриває низку перспективних напрямів впровадження технології засвоєння ієрогліфіки (як японської, так і китайської) для тих, хто вивчає ієрогліфічні мови як іноземні. Подальше поглиблене вивчення проблеми дії механізму когнітивних стилів на формування та відтворення образів графічних елементів ієрогліфічного письма може виявитися продуктивним на рівні дослідження різних за віком і статтю осіб, об'єднаних за навчальною чи професійною ознакою.

\section{Література}

Асадчих, О.В. (2007). Методика навчання студентів мовних спеціальностей усного японського монологічного мовлення на початковому етапі. Автореф. дис. канд. пед. наук. Київ.

Байрамова, С.И. (2016). Формирование слухопроизносительных навыков на основе когнитивного образа морфемы (китайский язык, неязыковой вуз) Автореф. дис. канд. пед. наук. Улан-Удэ.

Бондар, C.I. (2003). Психологічні особливості читання тексту іноземною мовою студентами з різним когнітивним стилем. Автореф. дис. канд. психол. наук. Київ.

Василюк, Ф.Е. (1993). Структура образа. Вопросы психологии, 5, 5-19.

Кочергин, И.В. (2006). Очерки лингводидактики китайского языка. Москва: АСТ. Восток - Запад.

Мартыненко, Н.П. (2007). Специфика семиотического изучения древнекитайских текстов. Автореф. дис. на д-ра философ. наук. Москва.

Методика «Пиктограмма» (опосредованное запоминание). (н. д.). Режим доступа: http://psy-clinic.info/index.php/testy/83-metodika-piktogrammaoposredovannoe-zapominanie

Методика «Свободная сортировка объектов». (н. д.). Режим доступа: https:// psylab.com.ua/tools

Методика «Сравнение похожих рисунков». (н. д.). Режим доступа: https://www. psylab.com.ua/tools

Методика «Фигуры Готттиальдта». (н. д.). Режим доступа: https://ru.wikipedia. org/wiki/\%D0\%A2\%D0\%B5\%D1\%81\%D1\%82 \%D0\%B2\%D0\%BA\%D0\%BB\% D1\%8E\%D1\%87\%D1\%91\%D0\%BD\%D0\%BD\%D1\%8B\%D1\%85_\%D1\%84\%D $0 \% \mathrm{~B} 8 \% \mathrm{D} 0 \% \mathrm{~B} 3 \% \mathrm{D} 1 \% 83 \% \mathrm{D} 1 \% 80$

Молоткова, Ю.В. (2014). Обучение иероглифическому письму студентов языкового вуза (китайский язык). Автореф. дис. канд. пед. наук. Минск.

Наумова, Ю.С. (2019). Особливості засвоєння візуально-семантичних образів студентами у процесі вивчення іноземної мови 3 ієрогліфічною писемністю. Автореф. дис. канд. психол. наук. Київ. 
Резаненко, В.Ф. (1996). Формально-змістові взаємозв'язки елементів сучасної ієрогліфічної писемності. Дис. д-ра філол. наук. Київ.

Рубинштейн, С.Л. (1997). Человек и мир. Москва: Наука.

Стрижак, У.П. (2005). Система обучения иероглифической письменности: Японский язык. Дис. канд. пед. наук. Москва.

Сімонок, В.П. (2014). Реалізація нових підходів до викладання іноземної мови. Матеріали ХХІІ-ХХІІІ засідань школи-семінару "Нові підходи до навчання іноземної мови» (м. Харків, 14 листопада 2014 р.), (с. 67-74). Харьков: Видавництво «Харківський національний університет імені В.Н. Каразіна».

Холодная, М.А. (2002). Когнитивные стили: о природе человеческого ума. Москва: ПЕР СЭ.

Шевченко, Н.Ф. (2018). Вивчення ефективності навчання іноземній мові у закладах вищої освіти: психологічна складова. І.О. Корнієнко (Гол. ред.), Психологія: теорія і практика (Вип. 2, с. 135-142). Мукачево: Вид-во РВВ МДУ.

Щедровицкий, Г.П. (2005). Мышление. Понимание. Рефлексия. Москва: Наследие ММК.

Кай, Янь. (2012). Отражение образа мира во внутренней форме иероглифического письма. В.В. Красных \& А.И. Изотов (Отв. ред.), Язык, сознание, коммуникация (Вып. 45, с. 77-86). Москва: Изд-во МАКС Пресс.

Jing, Liu. (2010). Language Learning Strategies and Its Training Model. International Education Studies, 3 (3), 100-104. https://doi.org/10.5539/ies.v3n3p100

Okita, Y. (2013). Kusho and Kanji learning by beginning Japanese language learners from non-Chinese character areas. Proceedings of the $11^{\text {th }}$ Conference of the Japanese Society for Cognitive Psychology (p. 86). https://doi.org/10.14875/ cogpsy.2013.0_86

Toyoda, E. (2001). Learning strategies employed for learning words written in Kanji Versus Kana. Australian Review of Applied Linguistics, 24 (2), 1-16. https://doi. org/10.1075/aral.24.2.01kub

吉田, 篤矢 \&菅谷 奈津恵. (2017). 漢字学習における空書の効果 : 非漢字圏日本語 学習者を対象として、第二言語としての日本語の習得研究, 20, 98-115.

小林, 由子. (2009). 字学習教育におけるメ夕認知 研究の役割. 日 本語 教育方法研 究 会誌, 9 (2), 14-15. Retrieved from: https://www.jstage.jst.go.jp/ article/jlem/9/2/9_KJ00008196814/_pdf/-char/ja

\section{References}

Asadchih, O.V. (2007). Metodyka navchannia studentiv movnykh spetsialnostei usnoho yaponskoho monolohichnoho movlennia na pochatkovomu etapi [Methods of Teaching Oral Japanese Monological Statements the Elementary Level Students of Language Departments]. Extended abstract of candidate's thesis. Kyiv [in Ukrainian].

Bayramova, S.I. (2016). Formirovanie sluhoproiznositelnyih navyikov na osnove kognitivnogo obraza morfemyi (kitayskiy yazyik, neyazyikovoy vuz) [Formation of auditory-pronunciation skills based on a cognitive image of a morpheme (Chinese, non-linguistic university)]. Extended abstract of candidate's thesis. Ulan-Ude: Buryatcky SU [in Russian]. 
Bondar, S.I. (2003). Psykholohichni osoblyvosti chytannia tekstu inozemnoiu movoiu studentamy $\mathrm{z}$ riznym kohnityvnym stylem [Psychological features of reading a text in a foreign language by students with various cognitive styles]. Extended abstract of candidate's thesis. Kyiv [in Ukrainian].

Vasilyuk, F. (1993). Struktura obraza [The structure of image]. Voprosyi psihologii Problems of Psychology, 5, 5-19 [in Russian].

Kochergin, I.V. (2006). Ocherki lingvodidaktiki kitayskogo yazyika [Essays on Chinese linguistics]. Moscow: AST.Vostok-Zapad [in Russian].

Martyinenko, N.P. (2007). Spetsifika semioticheskogo izucheniya drevnekitayskih tekstov [Specificity of the semiotic study of ancient Chinese texts]. Extended abstract of doctor's thesis. Moscow [in Russian].

Metodika "Piktogramma» (oposredovannoe zapominanie) [The technique of «Pictogram» (indirect memorization)]. (n. d.). Retrieved from: http://psy-clinic. info/index.php/testy/83-metodika-piktogramma-oposredovannoe-zapominanie

Metodika «Svobodnaya sortirovka ob'ektov» [The technique of "Free sorting of objects»]. (n. d.). Retrieved from: https://psylab.com.ua/tools

Metodika "Sravnenie pohozhih risunkov» [The technique of "Comparison of similar drawings»]. (n. d.). Retrieved from: https://www.psylab.com.ua/tools

Metodika «Figuryi Gottshaldta» [The technique of «Gottschaldt figures»]. (n. d.). Retrieved from: https://ru.wikipedia.org/wiki/\%D0\%A2\%D0\%B5\%D1\%81\%D1\% $82 \% \mathrm{D} 0 \% \mathrm{~B} 2 \% \mathrm{D} 0 \% \mathrm{BA} \% \mathrm{D} 0 \% \mathrm{BB} \% \mathrm{D} 1 \% 8 \mathrm{E} \% \mathrm{D} 1 \% 87 \% \mathrm{D} 1 \% 91 \% \mathrm{D} 0 \% \mathrm{BD} \% \mathrm{D} 0 \% \mathrm{~B}$ D\%D1\%8B\%D1\%85_\%D1\%84\%D0\%B8\%D0\%B3\%D1\%83\%D1\%80

Molotkova, Yu.V. (2014). Obuchenie ieroglificheskomu pismu studentov yazyikovogo vuza (kitayskiy yazyik) [Teaching hieroglyphic writing to students at a language university (Chinese)]. Extended abstract of candidate's thesis. Minsk: BSU [in Russian].

Naumova, Yu.S. (2018). Struktura protsesu zasvoiennia studentamy vizualnosemantychnoho obrazu iierohlifu [The structure of process of students' learning the visual-semantic representation of a hieroglyph]. Psiholingvistika Psycholinguistics, 23 (1), 258-273 [in Ukrainian].

Rezanenko, V.F. (1996). Formalno-zmistovi vzaiemozviazky elementiv suchasnoi iierohlifichnoi pysemnosti [Formal and substantive elements of the modern relationship of hieroglyphic writing]. Doctor's thesis. Kyiv: KSU [in Russian].

Rubinshteyn, S.L. (1997). Chelovek $i$ mir [Man and the World]. Moscow: Nauka [in Russian].

Strizhak, U.P. (2005). Sistema obucheniya ieroglificheskoy pismennosti: Yaponskiy yazyik [The System of Hieroglyphic Writing Training: the Japanese Language]. Candidate's thesis. Moscow: MGU [in Russian].

Simonok, V.P. (2014). Realizaciya novyh podhodov k prepodavaniyu inostrannogo yazyka [Realizing of new approaches to foreign language teaching]. Proceedings from Shkola-seminar «Novi pidkhody do navchannia inozemnoi movy» - Seminar materials «New Approaches to Learning a Foreign Language» (pp. 87-89). Kharkiv [in Ukrainian].

Kholodnaya, M.A. (2004). Kognitivnyie stili. O prirode individualnogo uma [Cognitive styles. About the nature of the individual mind]. SPb: Piter [in Russian].

Shevchenko, N.F. (2018). Vyvchennya efektyvnosti navchannya inozemnij movi u zakladax vyshhoyi osvity: psykholohichna skladova [Study of the effectiveness of foreign language teaching at higher educational institutions: psychological 
component]. In I.O. Korniyenko (Ed.), Psyhologia: teoriia i praktyka Psychology: Theory and Practice (Vol. 2, pp. 135-142). Mukachevo: MSU [in Ukrainian].

Schedrovitskiy, G.P. (2005). Myishlenie. Ponimanie. Refleksiya [Thinking. Understanding. Reflection]. Moscow: Nasledie [in Russian].

Kay, Yan. (2012). Otrajenie obraza mira vo vnutrenney forme ieroglificheskogo pisma [Reflection of the image of the world in the internal form of hieroglyphic writing]. In V.V. Krasnyih \& A.I. Izotov (Eds.), Yazyik, soznanie, kommunikatsiya Language, Consciousness, Communication (Vol. 45, pp. 77-86). Moscow: MAKS Press [in Russian].

Jing, Liu. (2010). Language Learning Strategies and Its Training Model. International Education Studies, 3 (3), 100-104. https://doi.org/10.5539/ies.v3n3p100

Okita, Y. (2013). Kusho and Kanji learning by beginning Japanese language learners from non-Chinese character areas. Proceedings of the $11^{\text {th }}$ Conference of the Japanese Society for Cognitive Psychology (p. 86). https://doi.org/10.14875/ cogpsy.2013.0 86

Toyoda, E. (2001). Learning strategies employed for learning words written in Kanji Versus Kana. Australian Review of Applied Linguistics, 24 (2), 1-16. https://doi. org/10.1075/aral.24.2.01kub

Yoshida, A. 吉田，篤矢 \& Sugaya, N. 菅谷 奈津恵. (2017). Kanji gakushū ni okeru kushō no kōka: hi kanji-ken Nihon gogakushūsha o taishō to shite 漢字学習に おける空書の効果：非漢字圏日本語学習者を対象として、[The Effect of Air Writing on Learning Kanji: A Study of Japanese Learners coming from a NonKanji Orthographic Background]. Dainigengo to shite no nihongo no shütoku $k e n k y \bar{u}$ 《第二言語としての日本語の習得研究》-Acquisition of Japanese as a Second Language, 20, 98-115 [in Japanese].

Kobayashi, Y. 小 林, 由子. (2009). Kanji gakushū Kyōiku ni okeru meta ninchi kenkyū no yakuwari字学習教育におけるメ夕認知研究の役割. [Role of 《Metacognition»Study for Kanji Learning and Teaching]. 《日 本語 教育方法研 究 会誌》- Japanese Journal of Educational Methods Research, 9 (2). 14-15. Retrieved from: https://www.jstage.jst.go.jp/article/jlem/9/2/9_KJ00008196814/_ $\mathrm{pdf} /$-char/ja [in Japanese].

\section{АНОТАЦІЯ}

Вступ. У статті висвітлено психолінгвістичні особливості засвоєння студентами візуально-семантичного образу ієрогліфу при вивченні японської мови. Вибір категорії образу обгрунтовано його здатністю відображувати в свідомості індивіда цілісну картину предмета пізнання, що відповідає специфріці ієрогліфічного письма. Візуально-семантичний образ ієрогліфрічного знака визначено як складний когнітивний комплекс (розумовий образ), який $\epsilon$ інтегральним продуктом візуального сенсорно-перцептивного сприйняття усіх графічних елементів формальної структури ієрогліфу, цілісного уявлення про нього та понятійного відображення, закріпленого у значенні.

Мета статmі - презентувати результати дослідження психолінгвістичних особливостей засвоєння студентами візуально-семантичних образів ієрогліфрів. Основним психодіагностичним інструментарієм обрано методики 
«Піктограми» О. Лурія, «Приховані фрігури» К. Готтшальдта, «Порівняння схожих малюнків» Дж. Кагана, «Вільне сортування об'єктів» Р. Гарднера у модифікації В. Колга.

Результати. Представлено результати теоретичних розвідок щодо психологічних особливостей проблеми засвоєння особистістю іноземних мов $і$ ієрогліфрічних, зокрема. Показано, що інтерпретаційні можливості ієрогліфрічних знаків докорінно відрізняються від звичного для європейського способу мовної кодифрікації дійсності і що шляхи оптимізації засвоєння східних мов мають грунтуватись на відмінностях між фонематичною та ієрогліфрічною писемністю. Розкрито психолінгвістичні особливості засвоєння студентами візуально-семантичного образу ієрогліру - характер та структура створених студентами візуальних та образів значень ієрогліфів мають суттєво виражену індивідуальність. Вивчення індивідуальних когнітивних стилів засвоєння студентами навчальної інформації засвідчило, що окремі когнітивні вміння та здібності виступають одними з чинників цієї успішності у комбінації з іншими; результативність засвоєння ієрогліфіки поліпшується при хорошому володінні уміннями систематизувати, узагальнювати, об'єднувати одиниці у широкі класи, а також при схильності до розсудливості.

Ключові слова: ієрогліф, ієрогліфрічна писемність, візуально-семантичний образ ієрогліфу, когнітивний стиль засвоєння навчальної інформачії.

Долинская Любовь, Наумова Юлия \& Шевченко Наталия. Психолингвистические особенности усвоения студентами визуально-семантического образа иероглифа при изучении японского языка

\section{АННОТАЦИЯ}

Вступление. В статье представлены психолингвистические особенности усвоения студентами визуально-семантического образа иероглифа при изучении японского языка. Выбор категории образа обоснован его способностью отображать в сознании индивида целостную картину предмета познания, соответствующую специфике иероглифического письма. Визуально-семантический образ иероглифического знака определён как сложный когнитивный комплекс (умственный образ), который является интегральным продуктом визуального сенсорно-перцептивного восприятия всех графических элементов формальной структуры иероглифа, целостного представления о нем и понятийного отражения, закреплённого в смысле.

Цель статьи - представить результаты исследования психолингвистических особенностей усвоения студентами визуально-семантических образов иероглифов. Основным психодиагностическим инструментарием избраны методики "Пиктограммы» А. Лурия, "Скрытые фигуры» К. Готтшальдта, "Сравнение похожих рисунков" Дж. Кагана, "Свободная сортировка объектов» Р. Гарднера в модификации В. Колга.

Результаты. Представлены результаты теоретических исследований по психологчческих особенностей проблемы усвоения личностью иностранных 
языков и иероглифических, в частности. Показано, что интерпретационные возможности иероглифических знаков в корне отличаются от привычного для европейского образа языковой кодификации действительности и пути оптимизации усвоения восточных языков должны основываться на различиях между фонематического и иероглифической письменностью. Раскрыты психолингвистических особенности усвоения студентами визуальносемантического образа иероглифа - характер и структура созданных студентами визуальных и образов значений иероглифов имеют существенно выраженную индивидуальность. Изучение индивидуальных когнитивных стилей усвоения студентами учебной информации показало, что отдельные когнитивные умения и способности выступают одними из факторов этой успешности в комбинации с другими; результативность усвоения иероглифики улучшается при хорошем владении умениями систематизировать, обобщать, объединять единицы в широкие классы, а также при склонности к рассудительности.

Ключевые слова: иероглиф, иероглифическая письменность, визуальносемантический образ иероглифа, когнитивный стиль усвоения учебной информации. 